\title{
Effect of heat on the anaphylactic-sensitising capacity of cows' milk, goats' milk, and various infant formulae fed to guinea-pigs
}

\author{
P MCLAUGHLAN, K J ANDERSON, ELSIE M WIDDOWSON, AND R R A COOMBS \\ Division of Immunology, Department of Pathology, and Department of Medicine, University of Cambridge, \\ Addenbrooke's Hospital, Hills Road, Cambridge
}

SUMmARY Cows' milk-fresh, boiled, and processed in different ways for the domestic market, and various infant milk formulae-was investigated for its sensitising capacity in the guinea-pig after being fed for 37 days. The anaphylactic sensitising capacity was considerably reduced by heat-treatment. As heat becomes more intense and more prolonged so $\beta$-lactoglobulin and casein become less sensitising. It should be stressed that these were results from experiments on guinea-pigs drinking milk. Should they be found to apply to the human infant too, it seems that it would not be impossible to manufacture a non-sensitising but fully nutritive milk product. The sensitising capacity of fresh and boiled goats' milk was examined too, and it was found that boiling reduced the sensitising capacity to an even greater extent than was the case with cows' milk.

In recent years there has been a resurgence of interest in breast feeding. Human milk is once again popularly recognised as being a nutritionally adequate diet for the human infant. The protective properties of human milk in terms of local protection against gastrointestinal and systemic infection are recognised. However, in Western countries, babies are still mainly bottle fed. Although most infants thrive on bottle feeding with preparations based on cows' milk without any apparent ill effects, a few develop some form of sensitisation to cows' milk and become unable to tolerate it because of gastrointestinal, dermatological, or respiratory problems.

As part of a larger study on the relevance of cows' milk sensitivity to the sudden infant death syndrome, a guinea-pig model for studying anaphylactic sensitivity to cows' milk has been developed. ${ }^{1}$ It has been shown that guinea-pigs, after drinking milk ad libitum for 37 days, develop anaphylactic sensitisation. $^{2}$

Recently, using this guinea-pig model, the sensitising capacity of various infant formulae and cows' milk preparations was compared. ${ }^{3}$ It was found that infant formulae varied considerably in their sensitising capacity per os, particularly in regard to sensitisation to $\beta$-lactoglobulin ( $\beta L G)$. It was found that after 37 days of drinking either ultra heat-treated milk, or spray-dried whole cows' milk (reconstituted with water), severe anaphylactic reactions could be provoked by injecting the guinea-pigs with $\beta L G$ either intravenously ${ }^{3}$ or intratracheally. ${ }^{24}$ In contrast, anaphylactic reactions to $\beta$ LG could not be similarly provoked in guineapigs that had been drinking 'evaporated milks'. Since these three types of milk consisted simply of whole cows' milk it seemed that the physical treatment to which the milks had been subjected was responsible for this variation in sensitising capacity. Accordingly it was decided to investigate in greater detail the effect of heating milk for different times and to varying degrees on its anaphylactic properties in the guinea-pig, and to include milk from the goat as well as the cow.

Infants today are rarely fed on whole cows' milk, but on a variety of proprietary formulae based on cows' milk heated and treated in different ways. These formulae are designed to resemble human milk to a greater or lesser extent, especially with regard to the concentration of protein and inorganic constituents, particularly sodium and phosphorus, but little attention has been given to lowering the sensitising capacity of bovine milk proteins. The present study was designed to test such infant foods, compare the results with whole cows' milk treated 
in various ways, and as far as possible, to relate the results obtained with the proprietary foods to the treatment they receive during manufacture. SMA formulae were selected for special study since the same ingredients are subjected to a different heat treatment in the manufacture of each preparation.

\section{Materials and methods}

Guinea-pigs. Female Dunkin-Hartley guinea-pigs aged 2-4 weeks on arrival from a commercial breeder (Bantin and Kingman) were used. At the start of each experiment the guinea-pigs were aged 4-6 weeks.

Diets. RGP guinea-pig pelleted diet (Rank, Hovis, McDougall) was fed to the animals. This pelleted diet had been shown to be free of cows' milk by immunological testing. The guinea-pigs received water or milk to drink ad libitum as indicated.

Milks tested. Table 1 gives a description of the milks studied. There were 6 kinds of liquid whole cows' milk differing only in the heat treatment each had received, one liquid skimmed milk, one spraydried whole cows' milk, and one spray-dried skimmed cows' milk. There were also 4 varieties of the proprietary infant formula known as SMA, and goats' milk - both unheated and boiled.

All infant formulae were prepared as recommended for infant feeding at about comparable protein concentrations $(20 \mathrm{mg} / \mathrm{ml}$ protein, Lowry estimation).
Controls. Each experiment included a group of guinea-pigs drinking water and a group drinking pasteurised milk. These two groups were challenged by injection with pasteurised milk on day 37 . All the animals that drank water remained unaffected, but all the animals that drank milk died of anaphylaxis.

Milk and isolated milk proteins for intravenous challenge. Before injection the milks were centrifuged at $10000 \times g$ for $5 \mathrm{~min}$ in a Hawksley microfuge to clear the inoculum of fat and insoluble material.

Isolated milk proteins-namely $\beta$ LG and caseinwere obtained from the National Institute for Research in Dairying, Shinfield.

The intravenous challenge consisted of $0.5 \mathrm{ml}$ of either microfuged milk at the concentration fed or isolated milk protein at a concentration of $6 \mathrm{mg} / \mathrm{ml}$.

Passive cutaneous anaphylaxis reactions. The guineapigs were bled by cardiac puncture on day 35 for passive cutaneous anaphylaxis (PCA) testing. ${ }^{4}$ The sera were diluted 1:2 for intradermal injection and thus could underestimate low serum levels of skin sensitising antibodies.

\section{Results}

\section{Experiment 1.}

Anaphylactic sensitivity of guinea-pigs (drinking various cows' milk preparations) to the milk fed, and also to $\beta L G$ and casein

In previous studies guinea-pigs, after drinking milk

Table 1 Composition and treatment of milks

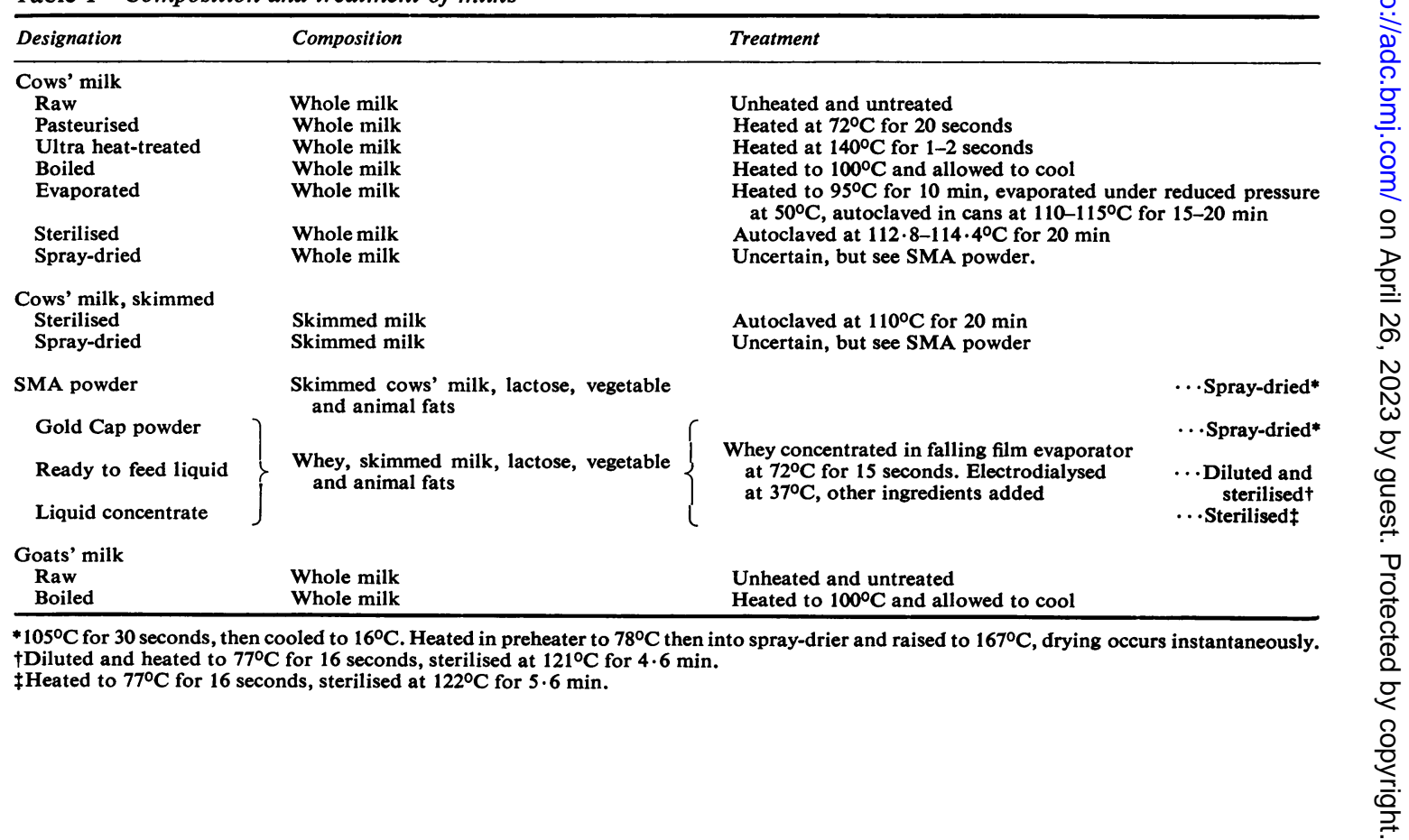


for 37 days, were tested for sensitisation by challenge with isolated milk proteins-namely $\beta L G$ and casein. It was considered that whole milk (as fed) would provide a more critical challenge. In this experiment the animals were challenged with whole milk (as fed), and with $\beta L G$ and casein.

Groups of guinea-pigs were given various formulae to drink for 37 days (Table 2). Each guinea-pig was bled on day 35 and the serum was used to study the PCA reaction. On day 37 each was challenged by intravenous injection of either the milk preparation as fed, or $\beta L G$, or casein, and the anaphylactic sensitivity was observed. The reactions are shown in Table 2.

The water-drinking control animals were unaffected. As expected a higher incidence of anaphylactic sensitivity was shown when the animals were challenged with the whole milk rather than the isolated milk proteins. Even so the percentage of anaphylaxis recorded was less in the St Ivel (evaporated milk) and SMA liquid concentrate groups than in the group drinking ultra heat-treated milks, and the reactions were also less severe. The PCA reactions, using sera from the blood taken on day 35 , agreed with the results of the in vivo challenge.

It may be concluded from this experiment that evaporated milk and SMA Gold Cap liquid concentrate were much less sensitising than whole cows' milk (ultra heat-treated). This was also the case with regard to sensitisation to $\beta L G$ and casein. In fact, the evaporated milk produced no sensitisation at all to $\beta$ LG. ${ }^{3}$

\section{Experiment 2.}

Effect of heat on whole cows' milk with respect to its anaphylactic sensitising capacity per os in the guinea-pig

In order to study more particularly the effect of heat on cows' milk, several preparations of whole milk were tested. In these milks the proportions of the constituents had not been altered (unlike infant formulae), they differed therefore only in the heat treatment they had received.

Groups of 10 guinea-pigs were given variously treated whole cows' milk (Table 3) to drink for 37 days. On day 35 each was bled and the serum was used to study the PCA reaction. On day 37 the guinea-pig was challenged by intravenous injection of the milk fed (Table 3). Raw milk - that is, direct from the cow and cooled by standing at room temperature-was fed to the guinea-pigs and proved to be sensitising to all the animals which drank it. Pasteurised milk (which is heated only to $71 \cdot 6^{\circ} \mathrm{C}$ for 20 seconds) was as sensitising as raw milk; ultra heat-treated milk, which is heated to a higher temperature for a shorter time $\left(140^{\circ} \mathrm{C}\right.$ for $1-2$ seconds), was slightly less sensitising. By simply bringing raw cows' milk to the boil and then allowing it to cool, its anaphylactic sensitising capacity could be considerably reduced (with respect to fatal anaphylaxis). From the PCA reactions (Table 3) it can be seen that the effect of boiling was greatest on the sensitising capacity of the $\beta$ LG. Evaporated milk, which is heated for a long period (about 20 min) at a high temperature $\left(110-115^{\circ} \mathrm{C}\right)$, proved to be least sensitising as regards fatal anaphylaxis. Again the PCA results showed that the $\beta L G$ had been rendered non-sensitising per os.

This experiment showed that the oral sensitising capacity of milk was inversely related to the degree of heat used in the preparation of the final milk product.

Goats' milk was also included in this experiment since it has been suggested that certain cows' milkintolerant infants are able to tolerate goats' milk. When given in its raw state to guinea-pigs, goats' milk proved to be as sensitising as raw cows' milk. The effect of boiling on goats' milk was even

Table 2 Percentage of anaphylaxis after intravenous challenge using preparation fed, compared with challenge using isolated milk proteins

\begin{tabular}{|c|c|c|c|c|c|c|c|c|c|}
\hline \multirow[t]{3}{*}{ Milk fed } & \multicolumn{9}{|c|}{ Percentage of anaphylaxis after intravenous challenge } \\
\hline & \multicolumn{3}{|c|}{ With preparation fed } & \multicolumn{3}{|c|}{ With $\beta$-lactoglobulin } & \multicolumn{3}{|c|}{ With casein } \\
\hline & Fatal & Non-fatal & Total & Fatal & Non-fatal & Total & Fatal & Non-fatal & Total \\
\hline $\begin{array}{l}\text { Whole cows' milk } \\
\text { Ultra heat-treated } \\
\text { Evaporated (St Ivel) }\end{array}$ & $\begin{array}{l}70(7 / 10) \\
50(5 / 10)\end{array}$ & $\begin{array}{l}20(2 / 10) \\
30(3 / 10)\end{array}$ & $\begin{array}{l}90(9 / 10) \\
80(8 / 10)\end{array}$ & $\begin{array}{l}60(6 / 10) \\
0(0 / 10)\end{array}$ & $\begin{array}{l}20(2 / 10) \\
0(0 / 10)\end{array}$ & $\begin{array}{l}80(8 / 10) \\
0(0 / 10)\end{array}$ & $\begin{array}{l}89(8 / 9) \\
0(0 / 5)\end{array}$ & $\begin{array}{l}11(1 / 9) \\
20(1 / 5)\end{array}$ & $\begin{array}{l}100(9 / 9) \\
20(1 / 5)\end{array}$ \\
\hline $\begin{array}{l}\text { SMA gold cap liquid } \\
\text { concentrate }\end{array}$ & $\mathbf{0}(0 / 8)$ & $75(6 / 8)$ & $75(6 / 8)$ & $7(1 / 15)$ & $20(3 / 15)$ & $27(4 / 15)$ & $0(0 / 13)$ & $23(3 / 13)$ & $23(3 / 13)$ \\
\hline Water only* & $0(0 / 5)$ & $0(0 / 5)$ & $0(0 / 5)$ & $0(0 / 5)$ & $0(0 / 5)$ & $0(0 / 5)$ & $0(0 / 5)$ & $0(0 / 5)$ & $0(0 / 5)$ \\
\hline
\end{tabular}

Numbers in brackets are actual numbers of animals from which \% was derived.

*Challenged with pasteurised_milk. 
Table 3 Effect of heat on the sensitising capacity of cows' milk and goats' milk

\begin{tabular}{|c|c|c|c|c|c|c|}
\hline \multirow[t]{3}{*}{ Milk fed } & \multirow{2}{*}{\multicolumn{3}{|c|}{$\begin{array}{l}\text { Percentage of anaphylaxis on } \\
\text { intravenous challenge with preparation fed }\end{array}$}} & \multicolumn{3}{|c|}{ Percentage of $P C A$ positive } \\
\hline & & & & \multirow{2}{*}{$\begin{array}{l}\text { To preparation } \\
\text { fed }\end{array}$} & \multirow{2}{*}{$\begin{array}{l}\text { To bovine } \\
\quad \beta L G\end{array}$} & \multirow{2}{*}{$\begin{array}{l}\text { To bovine } \\
\text { casein }\end{array}$} \\
\hline & Fatal & Non-fatal & Total & & & \\
\hline \multicolumn{7}{|l|}{ Cows' milk } \\
\hline Untreated* & $100(10 / 10)$ & $0(0 / 10)$ & $100(10 / 10)$ & $100(10 / 10)$ & $100(10 / 10)$ & $100(10 / 10)$ \\
\hline Pasteurised & $100(10 / 10)$ & $0(0 / 10)$ & $100(10 / 10)$ & $100(10 / 10)$ & $100(10 / 10)$ & $100(10 / 10)$ \\
\hline Ultra heat-treated & $70(7 / 10)$ & $20(2 / 10)$ & $90(9 / 10)$ & $80(8 / 10)$ & $60(6 / 10)$ & $80(8 / 10)$ \\
\hline Boiled $\dagger$ & $60(6 / 10)$ & $30(3 / 10)$ & $90(9 / 10)$ & $60(6 / 10)$ & $30(3 / 10)$ & $60(6 / 10)$ \\
\hline Evaporated & $50(5 / 10)$ & $30(3 / 10)$ & $80(8 / 10)$ & $70(7 / 10)$ & $0(0 / 10)$ & $60(6 / 10)$ \\
\hline \multicolumn{7}{|l|}{ Goats' milk } \\
\hline Untreated* & $100(10 / 10)$ & $0(0 / 10)$ & $100(10 / 10)$ & $100(10 / 10)$ & $100(10 / 10)$ & $100(10 / 10)$ \\
\hline Boiled $\dagger$ & $23(2 / 9)$ & $77(7 / 9)$ & $100(9 / 9)$ & $70(7 / 10)$ & $30(3 / 10)$ & $70(7 / 10)$ \\
\hline
\end{tabular}

* Milk, direct from animal and allowed to cool. †Untreated milk which was brought to the boil then allowed to cool.

Numbers in brackets are actual numbers of animals from which $\%$ was derived.

greater than for boiled cows' milk, the reduction in fatal anaphylaxis being from $100 \%$ with the unboiled milk, to $23 \%$ with the boiled milk (Table 3 ). The PCA results again showed that the sensitising capacity of $\beta L G$ was substantially reduced by boiling.

\section{Experiment 3.}

Anaphylactic sensitivity of guinea-pigs after drinking either whole or skimmed bottled sterilised milk, or whole or skimmed spray-dried milk

In experiment 2 the most strongly heated milk-that is, evaporated milk - was shown to be least sensitising. It was therefore, decided to investigate the anaphylactic sensitising capacity of other heated milks. For this purpose bottled sterilised milk, which is subjected to prolonged heating at a high temperature, was chosen. Since both whole cows' milk and skimmed milk are commercially available in sterilised form each was used in this experiment. For comparison spray-dried whole cows' milk and spray-dried skimmed milk were included.

Groups of 10 guinea-pigs were given either sterilised milk (whole or skimmed), or spray-dried milk (whole or skimmed) for 37 days. On day 35 each was bled by cardiac puncture and the serum from this blood was used for PCA tests. On day 37 the guinea-pig was challenged intravenously with the preparation fed.

The results of the intravenous challenge and the PCA reactions are given in Table 4 . The more highly heated products (that is, the bottled sterilised milks) were less sensitising than the spray-dried powders. Also, and of considerable interest, it was clear that both the skimmed milk products were less sensitising than the full cream whole milk products.

\section{Experiment 4.}

Effect of heat on infant formulae with respect to anaphylactic sensitising capacity per os in the guinea-pig Unlike whole cows' milk, in which the constituents are present in relatively stable proportions, the constituents of infant formulae show considerable variation between one brand and another. Groups of 8-16 guinea-pigs were given, for 37 days, 4 different infant formulae all of which were produced by the same manufacturer and contained the same fat mixture. One of them, SMA powder, was prepared from skimmed milk, while the other 3

Table 4 Sensitising capacity of whole and skimmed bottled sterilised milk and whole and skimmed spray-dried milk

\begin{tabular}{|c|c|c|c|c|c|c|}
\hline \multirow[t]{3}{*}{ Milk fed } & \multirow{2}{*}{\multicolumn{3}{|c|}{$\begin{array}{l}\text { Percentage of anaphylaxis on } \\
\text { intravenous challenge with preparation fed }\end{array}$}} & \multicolumn{3}{|c|}{ Percentage of $P C A$ positive } \\
\hline & & & & \multirow{2}{*}{$\begin{array}{l}\text { To preparation } \\
\text { fed }\end{array}$} & \multirow{2}{*}{$\begin{array}{l}\text { To bovine } \\
\beta L G\end{array}$} & \multirow{2}{*}{$\begin{array}{l}\text { To bovine } \\
\text { casein }\end{array}$} \\
\hline & Fatal & Non-fatal & Total & & & \\
\hline $\begin{array}{l}\text { Whole milk powder } \\
\text { (spray-dried) }\end{array}$ & $\begin{array}{l}100 \\
(10 / 10)\end{array}$ & $\begin{array}{c}0 \\
(0 / 10)\end{array}$ & $\begin{array}{l}100 \\
(10 / 10)\end{array}$ & $\begin{array}{l}100 \\
(10 / 10)\end{array}$ & $\begin{array}{l}100 \\
(10 / 10)\end{array}$ & $\begin{array}{l}20 \\
(2 / 10)\end{array}$ \\
\hline $\begin{array}{l}\text { Skimmed milk powder } \\
\text { (spray-dried) }\end{array}$ & $\begin{array}{l}60 \\
(6 / 10)\end{array}$ & $\begin{array}{l}30 \\
(3 / 10)\end{array}$ & $\begin{array}{l}90 \\
(9 / 10)\end{array}$ & $\begin{array}{l}70 \\
(7 / 10)\end{array}$ & $\begin{array}{l}40 \\
(4 / 10)\end{array}$ & $\begin{array}{l}20 \\
(2 / 10)\end{array}$ \\
\hline Whole milk sterilised & $\begin{array}{c}60 \\
(6 / 10)\end{array}$ & $\begin{array}{l}40 \\
(4 / 10)\end{array}$ & $\begin{array}{l}100 \\
(10 / 10)\end{array}$ & $\begin{array}{c}70 \\
(7 / 10)\end{array}$ & $\begin{array}{c}10 \\
(1 / 10)\end{array}$ & $\begin{array}{l}50 \\
(5 / 10)\end{array}$ \\
\hline Skimmed milk sterilised & $\begin{array}{c}30 \\
(3 / 10)\end{array}$ & $\begin{array}{l}50 \\
(5 / 10)\end{array}$ & $\begin{array}{c}80 \\
(8 / 10)\end{array}$ & $\begin{array}{c}60 \\
(6 / 10)\end{array}$ & $\begin{array}{c}0 \\
(0 / 10)\end{array}$ & $\begin{array}{l}50 \\
(5 / 10)\end{array}$ \\
\hline
\end{tabular}

Numbers in brackets are actual numbers of animals from which $\%$ was derived. 
(designated Gold Cap) were prepared from a common basic mixture but produced either as a powder, a ready-to-feed liquid, or a liquid concentrate (Table 5). The heating process for each of these preparations is described in Table 1.

As shown by direct challenge and PCA reactions (Table 4) these formulae differed in their sensitising capacity per os when fed to guinea-pigs. As the Gold Cap preparations consist of the same ingredients the differences in sensitising capacity were likely to be associated with their processing. It appears that, as the heating process during their manufacture increases in both temperature and time, the anaphylactic sensitising capacity per os of the product decreases.

If the SMA and SMA Gold Cap powders have been spray-dried under the same conditions, the main difference between them lies in the constituents, Gold Cap powder containing more whey proteins than the original SMA powder, the latter containing more casein than whey proteins. Indeed the Gold Cap powder was more sensitising to $\beta L G$ and the original powder was slightly more sensitising to casein.

These results on the three varieties of SMA Gold Cap infant formula in which the protein comes from whey and skimmed milk confirm those on whole milk, in that the less the heating the greater the sensitising capacity.

\section{Experiment 5.}

An additional experiment with cows' milk and goats' milk to investigate whether there is cross-reactivity between these milks (vis à vis anaphylactic sensitising capacity)

Although it is sometimes claimed that cows' milkintolerant infants are able to tolerate goats' milk, it would be expected that, immunologically, bovine and caprine proteins would show close homology. This experiment was to see if cross-reactivity between these two milks could be shown after sensitisation per os.

Groups of 10 guinea-pigs were given either boiled cows' milk or boiled goats' milk to drink for 37 days and then challenged by intravenous injection, either with the milk fed or the opposing milk. On day 35 each was bled and the serum was used to study the PCA reaction.

The results of the intravenous challenge and PCA reactions are shown in Table 6. In both cases, whether sensitised per os to cows' milk or goats' milk, when challenged with the milk fed almost all animals were anaphylactically sensitive (to cows' milk $90 \%$, to goats' milk $100 \%$ ). However, when challenged with goats' milk, although sensitised to cows' milk, total anaphylaxis was only slightly less-that is $70 \%$ compared with $90 \%$-but fatal anaphylaxis was reduced from 60 to $10 \%$. Similarly when challenged with cows' milk, though sensitised to goats' milk, total anaphylaxis was

\section{Table 6 Cross-reactivity of cow and goat milks}

\begin{tabular}{|c|c|c|c|c|c|c|}
\hline \multicolumn{2}{|l|}{ Milk* } & \multicolumn{3}{|c|}{$\begin{array}{l}\text { Percentage of anaphylaxis } \\
\text { after intravenous challenge }\end{array}$} & \multicolumn{2}{|c|}{$\% P C A$ positive } \\
\hline Fed & $\begin{array}{l}\text { Used for } \\
\text { challenge }\end{array}$ & & Non-fatal & Total & $\begin{array}{l}\text { To cows' } \\
\text { milk }\end{array}$ & $\begin{array}{l}\text { To goats' } \\
\text { milk }\end{array}$ \\
\hline $\begin{array}{l}\text { Cow } \\
\text { Cow }\end{array}$ & Goat & $\begin{array}{l}60 \\
(6 / 10) \\
10 \\
(1 / 10)\end{array}$ & $\begin{array}{l}30 \\
(3 / 10) \\
60 \\
(6 / 10)\end{array}$ & $\begin{array}{l}90 \\
(9 / 10) \\
70 \\
(7 / 10)\end{array}$ & 45 & 15 \\
\hline $\begin{array}{l}\text { Goat } \\
\text { Goat }\end{array}$ & $\begin{array}{l}\text { Goat } \\
\text { Cow }\end{array}$ & $\begin{array}{l}50 \\
(5 / 10) \\
10 \\
(1 / 10)\end{array}$ & $\begin{array}{l}50 \\
(5 / 10) \\
70 \\
(7 / 10)\end{array}$ & $\begin{array}{l}100 \\
(10 / 10) \\
80 \\
(8 / 10)\end{array}$ & 50 & 55 \\
\hline
\end{tabular}

*Milk used for feeding and challenge in all cases was 'untreated' milk which had been brought to the boil and then allowed to cool.

Table 5 Comparison of 4 infant formulae all with the same fat composition, 3 were prepared from identical basic constituents but subjected to different manufacturing processes

\begin{tabular}{|c|c|c|c|c|c|c|c|c|c|}
\hline \multirow[b]{3}{*}{ Milk fed } & \multicolumn{9}{|c|}{ Percentage of anaphylaxis after intravenous challenge } \\
\hline & \multicolumn{3}{|c|}{ With preparation fed } & \multicolumn{3}{|c|}{ With $\beta$-lactoglobulin } & \multicolumn{3}{|c|}{ With casein } \\
\hline & Fatal & Non-fatal & Total & Fatal & Non-fatal & Total & Fatal & Non-fatal & Total \\
\hline Untreated cows' milk & $\begin{array}{l}100 \\
(10 / 10)\end{array}$ & $\begin{array}{l}0 \\
(0 / 10)\end{array}$ & $\begin{array}{l}100 \\
(10 / 10)\end{array}$ & NT & NT & NT & NT & NT & NT \\
\hline $\begin{array}{l}\text { SMA powder } \\
\text { Gold Cap powder }\end{array}$ & $\begin{array}{c}63 \\
(5 / 8) \\
75\end{array}$ & $\begin{array}{l}37 \\
(3 / 8) \\
25\end{array}$ & $\begin{array}{l}100 \\
(8 / 8) \\
100\end{array}$ & $\begin{array}{l}7 \\
(1 / 15) \\
31\end{array}$ & $\begin{array}{l}27 \\
(4 / 15) \\
25\end{array}$ & $\begin{array}{l}34 \\
(5 / 15) \\
56\end{array}$ & $\begin{array}{l}7 \\
(1 / 15) \\
0\end{array}$ & $\begin{array}{l}40 \\
(6 / 15) \\
40\end{array}$ & $\begin{array}{l}47 \\
(7 / 15) \\
40\end{array}$ \\
\hline $\begin{array}{l}\text { Gold Cap powder } \\
\text { Gold Cap, ready to feed }\end{array}$ & $\begin{array}{l}75 \\
(6 / 8) \\
12\end{array}$ & $\begin{array}{l}(2 / 8) \\
63\end{array}$ & $\begin{array}{l}100 \\
75\end{array}$ & $(5 / 16)$ & $\begin{array}{l}(4 / 16) \\
44\end{array}$ & $\begin{array}{l}(9 / 16) \\
50\end{array}$ & $\begin{array}{l}(0 / 15) \\
7\end{array}$ & $\begin{array}{l}(6 / 15) \\
40\end{array}$ & $\begin{array}{l}(6 / 15) \\
47\end{array}$ \\
\hline & $(1 / 8)$ & $(5 / 8)$ & $(6 / 8)$ & $(1 / 16)$ & $(7 / 16)$ & $(8 / 16)$ & $(1 / 15)$ & $(6 / 15)$ & $(7 / 15)$ \\
\hline Gold Cap liquid concentrate & $\begin{array}{c}0 \\
(0 / 8)\end{array}$ & $\begin{array}{l}75 \\
(6 / 8)\end{array}$ & $\begin{array}{c}75 \\
(6 / 8)\end{array}$ & $\begin{array}{l}7 \\
(1 / 15)\end{array}$ & $\begin{array}{l}20 \\
(3 / 15)\end{array}$ & $\begin{array}{l}27 \\
(4 / 15)\end{array}$ & $\begin{array}{l}0 \\
(0 / 13)\end{array}$ & $\begin{array}{l}23 \\
(3 / 13)\end{array}$ & $\begin{array}{l}23 \\
(3 / 13)\end{array}$ \\
\hline
\end{tabular}

NT $=$ not tested.

Numbers in brackets are actual numbers of animals from which $\%$ was derived. 
reduced from 100 to $80 \%$ with fatal anaphylaxis being reduced from 50 to $10 \%$. Thus it seems that there is simply a reduction in severity of anaphylactic reaction; presumably these less severe reactions were due to cross-reactivity.

\section{Discussion}

The studies described on guinea-pigs have clearly demonstrated that the heating of cows' milk removes some of its sensitising capacity for this species, and the more extensive the heating the greater the effect. Several questions are raised by these results. (1) Which of the milk proteins are the principal sensitising components and what changes does heating produce in them to reduce their sensitising capacity? (2) How relevant are these findings in guinea-pigs to the problem of milk allergy in infants and children? (3) Does heating affect the nutritive properties of milk?

Milk contains two rather different kinds of proteins; firstly, the caseins which are highly aggregated proteins of fixed amino-acid sequence but of irregular 3-dimensional structure; secondly, the whey proteins which are globular proteins with unique 3-dimensional structures. $\beta L G$ is the best known of these whey proteins, and it is also the most abundant. However, many other proteins are known to be present in the whey protein fraction of cows' milk.

The effect of heat on the two kinds of protein is different. Moderate heating, such as in pasteurisation or ultra heat treatment, produces little detectable change in the caseins; on the other hand, the whey proteins are partly denatured-they lose their unique 3-dimensional structures-resulting in decreases in their solubility and antigenicity. ${ }^{5}$ Greater heating, such as autoclaving, as in the preparation of evaporated milk, gives virtually complete denaturation of the whey proteins and produces chemical changes in both kinds of protein-for example, the Maillard reaction between carbohydrate and protein amino groups, and the loss of phosphate from phosphoserine to give dehydroalanine and lysinoalanine. Some of these chemical changes form cross-links between different protein molecules, resulting in lower solubility and poorer digestibility. The kinetics of denaturation and the Maillard and other reactions are such that in all the heat treatments (except pasteurisation) of the milks we have tested, both occur simultaneously, making it difficult to disentangle the details of how heating reduces the sensitising capacity of milk proteins; this requires further study.

It is appreciated that some variation in the final milk product may occur from batch to batch, but most of the milks and SMA products have been tested in several experiments with basically similar findings.

Concerning the applicability of the present experimental results in the guinea-pig to milk allergy in infants and to cot-death, it is difficult to be dogmatic. Cows' milk proteins are foreign to the human infant as they are to the guinea-pig and it does not seem unreasonable to suppose that heat treatment of milk might make it less sensitising to children as well as to guinea-pigs.

There is no evidence that heating milk has serious harmful effects on its nutritive value apart from some destruction of the heat-labile vitamins, notably vitamin $\mathrm{C}$, but these can easily be added. The production of lysinoalanine when milk is severely heated reduces the availability of the lysine in it. ${ }^{6}$ Reports that lysinoalanine is toxic to rats have not been confirmed. There are many reports describing the progress of infants fed on evaporated milk ${ }^{7-10}$ compared with infants fed on other cows' milk preparations. Almost all agree that evaporated milk is well tolerated and that infants grow well on it.

The results described in this paper suggest that heat treatment of infant formulae containing cows' milk proteins may be beneficial to infants receiving them. There would even seem to be the possibility that a fully nutritive milk product could be achieved which was totally non-sensitising. A further observation of considerable interest was the finding (Table 4) which suggests that skimmed milks may be less sensitising than full cream, whole milks. The fat globules could well facilitate absorption of intact antigenic protein across the gut wall and this now merits a special study. In the meantime it is suggested that manufacturers need not strive to apply as little heat as possible to their products.

We thank Mr R A Hendey, Cow and Gate Limited, Dr W F J Cuthbertson, Glaxo Research Limited, and Dr G Faux, John Wyeth and Brother Limited, for their co-operation, Dr Marie Coates and her colleagues, National Institute for Research in Dairying, Reading, for helpful discussion, $\mathrm{Dr}$ R L J Lyster, National Institute for Research in Dairying, Reading, for donating purified $\beta$ lactoglobulin and casein and for helping with the preparation of this paper; Miss $\mathbf{S}$ Raines gave technical assistance, and Miss L Cowell of the Central Animal Services of the University cared for the guinea-pigs on the special diets.

The work was supported by a grant from the Research Council. 


\section{References}

1 Parish W E, Richards C B, France N E, Coombs R R A. Further investigations on the hypothesis that some cases of cot-death are due to a modified anaphylactic reaction to cows' milk. Int Arch Allergy 1964; 24: 215-43.

2 Devey M E, Anderson K J, Coombs R R A, Henschel M J, Coates M E. The modified anaphylaxis hypothesis for cot-death. Anaphylactic sensitization in guinea-pigs fed cows' milk. Clin Exp Immunol 1976; 26: 542-8.

3 Anderson K J, McLaughlan P, Devey M E, Coombs R R A. Anaphylactic sensitivity of guinea-pigs drinking different preparations of cows' milk and infant formulae. Clin Exp Immunol 1979; 35: 454-61.

4 Coombs R R A, Devey M E, Anderson K J. Refractoriness to anaphylactic shock after continuous feeding of cows' milk to guinea-pigs. Clin Exp Immunol 1978; 32: 263-71.

5 Lyster R J L. Denaturation of $\alpha$-lactalbumin and $\beta$ lactoglobulin in heated milk. $J$ Dairy Res 1970; 37: 233-42.

- Manson W. Aspects of the value and limitations of milk protein as a food material. Proc Nutr Soc 1978; 37: 217-23.
7 Adams F H. A simple formula for premature and fullterm infants. $J$ Pediatr $1948 ; 33: 23-8$.

8 Vignec A J, McNamara $\mathrm{H}$, Barnett $\mathrm{H}$ L. Use of supplemented milk for infant feeding. Am J Dis Child 1948; 76: $154-68$.

9 Gruber S, Litvak A, Rascoff H, Norton R. The hospital progress of nine hundred and ninety two premature infants fed evaporated milk-carbohydrate mixtures. $J$ Pediatr 1949; 35: 70-6.

10 Abelson S M. Feeding of premature infants. Use of a simple formula. J Pediatr 1950; 37: 711-7.

Correspondence to Professor $\mathbf{R} \mathbf{R}$ A Coombs, University of Cambridge, Department of Pathology, Division of Immunology, Laboratories Block, Addenbrooke's Hospital, Hills Road, Cambridge CB2 2QQ.

Received 6 December 1979 